\title{
GLL
}

Geomatics, Landmanagement and Landscape No. $4 \cdot 2019,59-71$

\section{OPERATION OF ASG-EUPOS POZGEO SUB-SERVICE IN THE EVENT OF FAILURE OF REFERENCE STATIONS USED IN THE STANDARD SOLUTION - CASE STUDY}

\author{
Dawid Kudas, Agnieszka Wnęk
}

\begin{abstract}
Summary
The validation of the work of computational algorithms operating within the positioning system services under unusual measuring conditions is an important part of the entire system. Particularly noteworthy conditions are failures of reference stations forming the examined station network. The article evaluates the operation of the algorithm implemented to the POZGEO sub-service of the ASG-EUPOS system in the event of failure of reference stations used in the standard determination of the coordinates of the selected spatial point. The research material consisted of 117 days of continuous determination of the position of the selected spatial point using 1 hour of GPS static observations. Reports on the procedure of determining the position in the post-processing mode in POZGEO sub-service of static satellite observations were used to simulate the reduction of the number of tie vectors in coordinates' determination method. The resistance of the automatic post-processing algorithm to failure of parts from the standard reference stations used was assessed.
\end{abstract}

\section{Keywords}

$\mathrm{POZGEO} \bullet$ reference station failure $\bullet$ validation $\bullet$ automatic post-processing

\section{Introduction}

The Active Geodetic Network-EUPOS (ASG-EUPOS) is an example of a national active geodetic network based on EUPOS standards [Bosy et al. 2007, Bosy et al. 2008]. ASG-EUPOS was activated in Poland in 2008. Advantages and disadvantages of ASG-EUPOS in comparison to selected different national active geodetic network solutions were the subject of a study conducted at the beginning of ASG-EUPOS operation [Specht and Skóra 2009]. EUPOS includes also the following national networks of reference stations, among others: CZEPOS (Czech Republic), ESTPOS (Estonia), LITPOS (Lithuania), LATPOS (Latvia), RIGA EUPOS (the City of Riga), MOLDPOS (Moldavia), SAPOS (Germany), ROMPOS (Romania), SKPOS (Slovakia), and GNSSNet.hu (Hungary). These countries must apply EUPOS standards and guide- 
lines in order to develop their national active geodetic networks: EUPOS Technical Standards, EUPOS Guidelines for Cross-Border Data Exchange, EUPOS Guideline for EUPOS Reference Frame Fixing, and Guidelines for Single Site Design.

Currently, ASG-EUPOS consists of 103 reference stations (Fig. 1). In Poland, they make up the first-order and second-order horizontal national geodetic networks [Regulation 2012]. All the stations receive GPS satellite signals; 101 of them pick up GLONASS signals; and, following an upgrade, 92 stations receive Galileo and BeiDu signals [www.asgeupos.pl]. ASG-EUPOS supports cross-border data exchange with SKPOS, CZEPOS, SAPOS, and LITPOS [Krzeszowski and Bosy 2011]. ASG-EUPOS is supported by 24 foreign reference stations. Fifteen national reference stations and four foreign reference stations used by ASG-EUPOS belong to the European Permanent Network (EPN). Five ASG-EUPOS stations belong to the International GNSS Service (IGS).

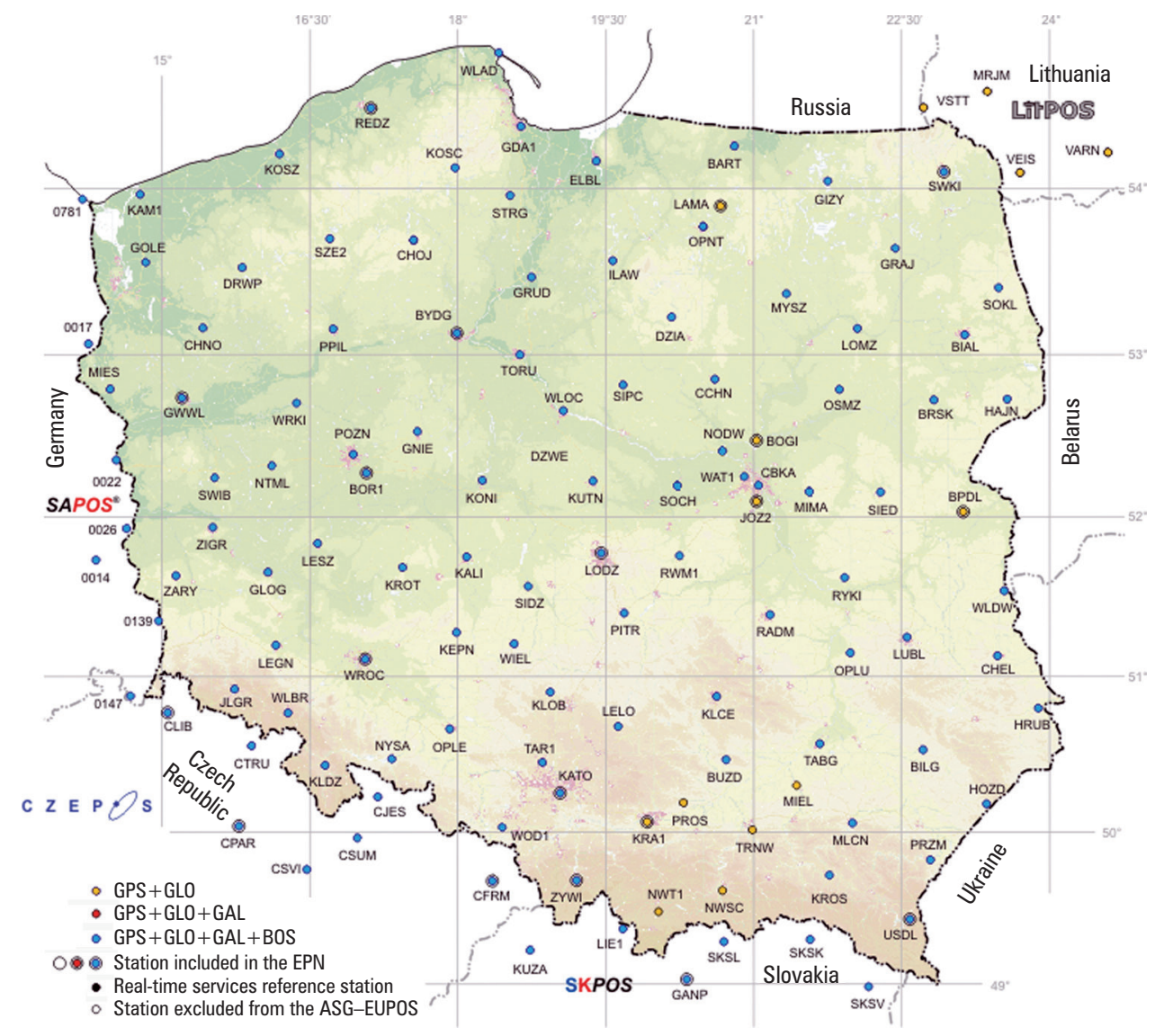

Source: www.asgeupos.pl

Fig. 1. Location of ASG-EUPOS stations 
ASG-EUPOS has four sub-services: NAWGEO, KODGIS/NAWGIS, NAWGIS, POZGEO and POZGEO-D. NAWGEO is intended for users requiring positioning in real-time with Real-Time Kinematics (RTK) and Network Real-Time Kinematics (NRTK) techniques. This sub-service is dedicated to land surveying and precision agriculture. The assumed positioning accuracy when using NAWGEO is $0.03 \mathrm{~m}$ horizontal and $0.05 \mathrm{~m}$ vertical [www.asgeupos.pl]. KODGIS and NAWGIS are intended for users of single-frequency code solutions. The assumed accuracy of real-time positioning when using KODGIS or NAWGIS ranges from $0.25 \mathrm{~m}$ to $3.00 \mathrm{~m}$ [www.asgeupos. pl]. POZGEO-D was designed for users who need historical GNSS observation data recorded at ASG-EUPOS reference stations. POZGEO is for users who do not have their own specialized software to carry out post-processing of GPS observations from static measurements, and who wish to use automatic post-processing (APPS) guaranteed by the ASG-EUPOS manager. The accuracy of coordinates when using POZGEO ranges from 0.01 to $0.10 \mathrm{~m}$ [www.asgeupos.pl], however, it depends on the duration of the measurement session and on other observation conditions. In Poland, as one of the few countries, the APPS algorithm has been developed individually, and is only linked to a sub-service of Trimble [Kadaj and Świętoń 2007a, 2007b, 2009, 2010]. In Polish APPS the position is determined on the basis of selection of observations collected at 6 out of 10 closest reference stations [Kadaj and Świętoń 2016]. In addition, APPS position determination is based on one of the two methods, depending on the length of the measurement session. The first method is dedicated to measuring sessions lasting less than 1.5 hours, and the second one is intended for sessions exceeding 1.5 hours [Kadaj 2008, 2010, 2012]. The POZGEO sub-service can be useful for determining coordinates of geodetic control network points and controlling their determination using other techniques [Kudas 2015]. At the time of this writing, the Polish APPS is still being developed and introduced to ASG-EUPOS.

The purpose of the study reported in this paper was to verify the work of a position determination using the dual-frequency GPS carrier phase observations with the duration of 1 hour, and implementing automatic post-processing algorithm in ASG-EUPOS, POZGEO sub-service. Real observational data was analysed, and based on that, a simulation of the correctness of coordinates determination in the event of failure of nearby reference stations was carried out. The information about APPS algorithm's resistance to the failure of nearby reference stations is of particular importance. The paper validated the operation of the automatic post-processing algorithm of POZGEO following the failure of one or more reference stations typically used in positioning operations for the selected measurement point.

\section{Material and methods}

The study used information from reports from the double carrier-phase difference automatic post-processing of 1 hour of static GPS observations with 1 s sampling interval in ASG-EUPOS POZGEO sub-service. Those observations were recorded from 1 to 119 DOY 2017 by the research reference station of the University of Agriculture 
in Kraków (KRUR). Trimble NetR9 receiver and TRM55971.00 TZGD antenna were used at KRUR station. In order to determine the position in typical conditions, the APPS algorithm selected observations from the 6 nearest reference stations. For the adopted observation site, and in typical conditions, the stations used in standard solution were KRA1, KATO, ZYWI, LELO, NWT1, and PROS. If observations from one of the optimal reference stations were not available, the position was determined based on a different station configuration, or based on spatial vectors to a smaller number of reference stations. In the analysed time span, there were 544 cases in which the position was determined based on observations from 6 reference stations other than the optimal reference stations, or with a smaller number of tie vectors - in the paper, these are referred to as alternative solutions. These alternative solutions account for $20 \%$ of all registered solutions in the analysed time span. Additional stations, from which observations were used in order to determine the position in case of failure of any of the typical stations used by APPS were BUZD and NWSC.

Table 1 shows the length of the tie vectors between the observation site and reference stations from both the optimal stations configuration and alternative solutions. In the case of optimal 6 tie reference stations, the tie vectors did not exceed the length of $70 \mathrm{~km}$, however in the case of references to alternative stations, the tie vectors length exceeded $75 \mathrm{~km}$.

Table 1. Length of the tie vectors between the observation site and reference stations

\begin{tabular}{|l|c|c|c|c|c|c|c|c|}
\hline Reference stations ID & KRA1 & PROS & KATO & ZYWI & NWT1 & LELO & BUZD & NWSC \\
\hline Tie vector length $[\mathrm{m}]$ & 5189 & 33400 & 61387 & 64084 & 68547 & 68595 & 75014 & 79345 \\
\hline
\end{tabular}

Source: Authors' own study

Among the 544 cases of alternative solutions in the analysed set, 469 were solutions based on a tie-in to the six reference stations. Of these, 444 cases involved five stations from the standard solution and the BUZD station. The largest set with a stable configuration of reference stations was identified in the set of 469 positions. This set of solutions was a result of tying-in to stations KRA1, KATO, ZYWI, LELO, NWT1, and BUZD, and it involved 305 positions. Based on this set, a simulation of determining the position of the point was carried out using a reference to 5, 4 and 3 reference stations from among the stations KRA1, KATO, ZYWI, LELO, NWT1 and BUZD (Fig. 2). For the simulated combinations, we have also verified whether the determined point was inside or outside the figure, whose vertices were defined by the chosen tie points.

In the analyses, the lengths of vectors between the determined positions in simulated combinations and the reference position were calculated based on the linear deviations. The sets of positions in the analysed combinations were assessed with regard to the distance to the reference point in $0.01 \mathrm{~m}$ intervals. Thereby, a unidimensional analysis of the sets of positions in a defined space of distances to the reference point was conducted. 


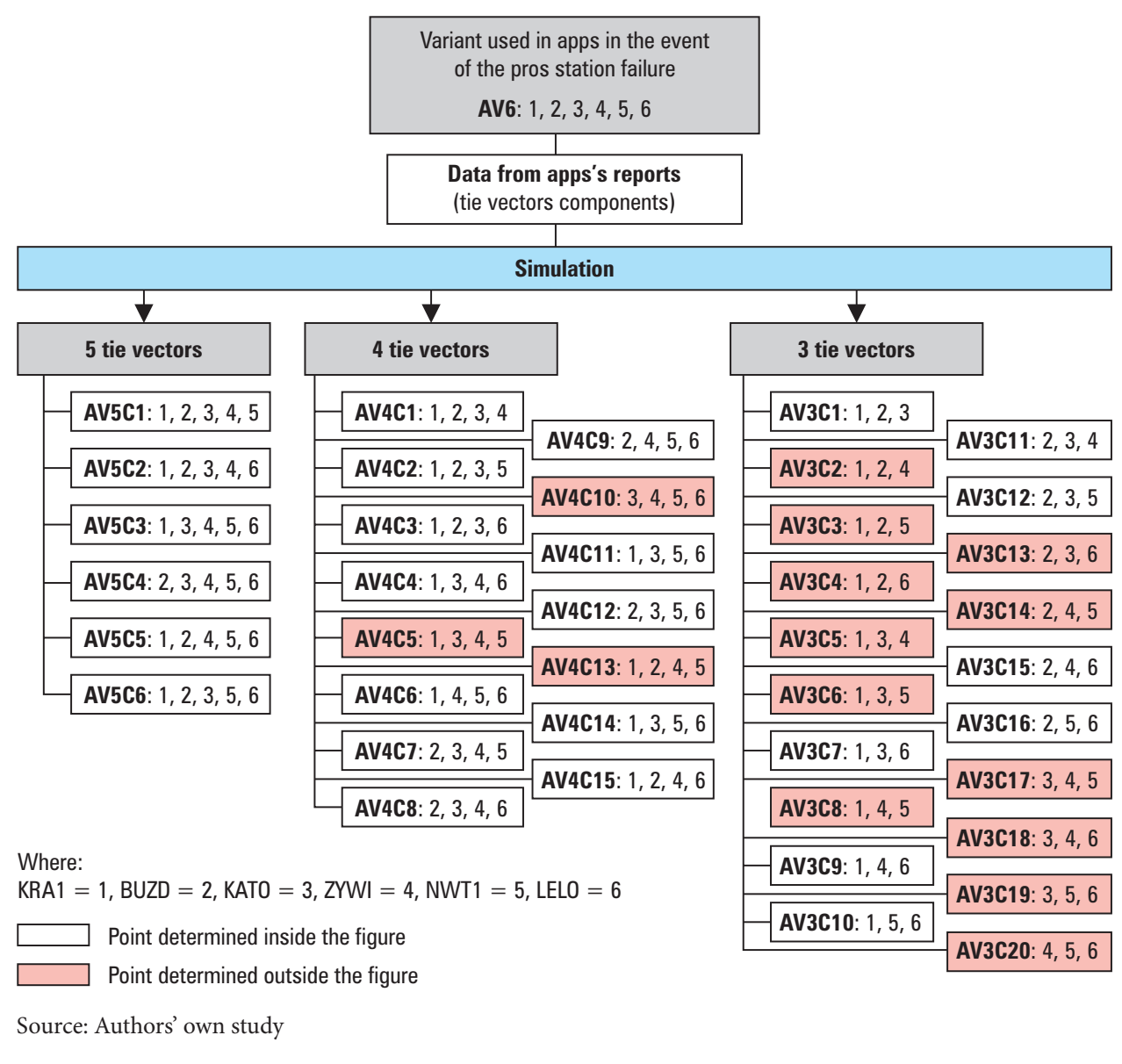

Fig. 2. Flow chart of the analysed combinations in simulation for the alternative solution based on reference stations KRA1, KATO, ZYWI, LELO, NWT1, and BUZD

Based on calculated standard deviations of the coordinates in simulation compared to the reference coordinates, accuracy measures were determined. The measures specify the 3D accuracy of the positions. The accuracy measures were used to evaluate simulated combinations and variants. The mean radial spherical error (MRSE) with $61 \%$ probability (Equation 1), 90\% spherical accuracy standard (SAS90) with 90\% probability (Equation 2) and 99\% spherical accuracy standard (SAS99) with 99\% probability (Equation 3) were applied. The values of the employed accuracy measures are represented as a radius of a sphere with the geometric centre at the reference position wherein the positions determined by the analysed combination occur at the assumed probability.

$$
\operatorname{MRSE}=\sqrt{\sigma_{X}^{2}+\sigma_{Y}^{2}+\sigma_{Z}^{2}}
$$




$$
\begin{aligned}
& \text { SAS90 }=0.833\left(\sigma_{X}+\sigma_{Y}+\sigma_{Z}\right) \\
& \text { SAS99 }=1.122\left(\sigma_{X}+\sigma_{Y}+\sigma_{Z}\right)
\end{aligned}
$$

where $\sigma$ - standard deviation.

The analyses were carried out for XYZ Cartesian coordinates in the PL-ETRF2000 system.

\section{Results}

Linear deviations from the reference coordinates of KRUR were calculated for the positions obtained using the alternative solutions (Fig. 3). Alternative solutions can be divided into the following ways of tie-in to:

1. KATO, ZYWI, LELO, BUZD

2. KATO, ZYWI, NWT1, LELO, BUZD, NWSC

3. KRA1, KATO, ZYWI, LELO, BUZD

4. KRA1, KATO, ZYWI, NWT1, LELO, BUZD

5. KRA1, KATO, ZYWI, NWT1

6. KRA1, PROS, KATO, NWT1, LELO, BUZD

7. KRA1, PROS, KATO, ZYWI, NWT1, BUZD

8. KRA1, PROS, ZYWI, NWT1, LELO, BUZD

9. PROS, KATO, ZYWI, NWT1, LELO, BUZD

Maximum values of linear deviations are $0.16 \mathrm{~m}$ for $\Delta \mathrm{X}$ and $\Delta \mathrm{Y}$ coordinates, and $0.18 \mathrm{~m}$ for $\Delta \mathrm{Z}$ coordinates. Mean linear deviations are: $0.01 \mathrm{~m}$ for $\Delta \mathrm{X}$ coordinates, and $0.00 \mathrm{~m}$ for $\Delta \mathrm{Y}$ and $\Delta \mathrm{Z}$ coordinates. Considering the case of the most numerous set, based on tie vectors to KRA1, KATO, ZYWI, LELO, NWT1and BUZD, the maximum values of linear deviations are $0.08,0.16$, and $0.09 \mathrm{~m}$ respectively for $\Delta \mathrm{X}, \Delta \mathrm{Y}$, and $\Delta \mathrm{Z}$ coordinates.

Using the stations involved in the most numerous alternative solutions, new combinations were developed and the presented analysis was performed. Linear deviations were determined for each new combination. They were then validated using mean values and standard deviations in relation to the reference values (Fig. 4).

Figure 3 shows the mean values and standard deviations for an alternative solution using 6 stations (AV6), and solutions simulated on its basis. The obtained values can also be compared to the mean value and standard deviation estimated on the basis of a set of solutions using the tie vectors to 6 typical reference stations. For standard solution, mean value equals $0.00 \mathrm{~m}$, and standard deviation equals $0.01 \mathrm{~m}$ for all deviations $\Delta \mathrm{X}, \Delta \mathrm{Y}$, and $\Delta \mathrm{Z}$. The resulting mean coordinates and their deviations for new combinations of tie vectors typically do not differ from mean values for the AV6 set. This is particularly evident for AV5C1, AV5C2, AV5C3, AV4C3, AV4C10, AV4C14, 
$\mathrm{AV} 3 \mathrm{C} 9$, and $\mathrm{AV} 3 \mathrm{C} 15$. Note that in the case of $\Delta \mathrm{Y}$ in 3-vector solutions, all combinations demonstrated rather good mean values but much greater standard deviations. The mean value and standard deviation of the linear deviation of the $\mathrm{Y}$ coordinate in the standard solution and the AV6 set are consistent. Furthermore, comparing the mean values and standard deviations obtained for individual simulated alternative solutions with the values obtained for the standard solution, we observe that in the case of a combination of 5 and 4 tie vectors, these values are similar to each other. In the case of combinations with 3 tie vectors, it is only the $\Delta \mathrm{X}$ mean values and standard deviations that exceed the values for the standard solution. For $\Delta \mathrm{Y}$ and $\Delta \mathrm{Z}$, it is evident that the mean values and standard deviations are comparable with the values for the standard solution.
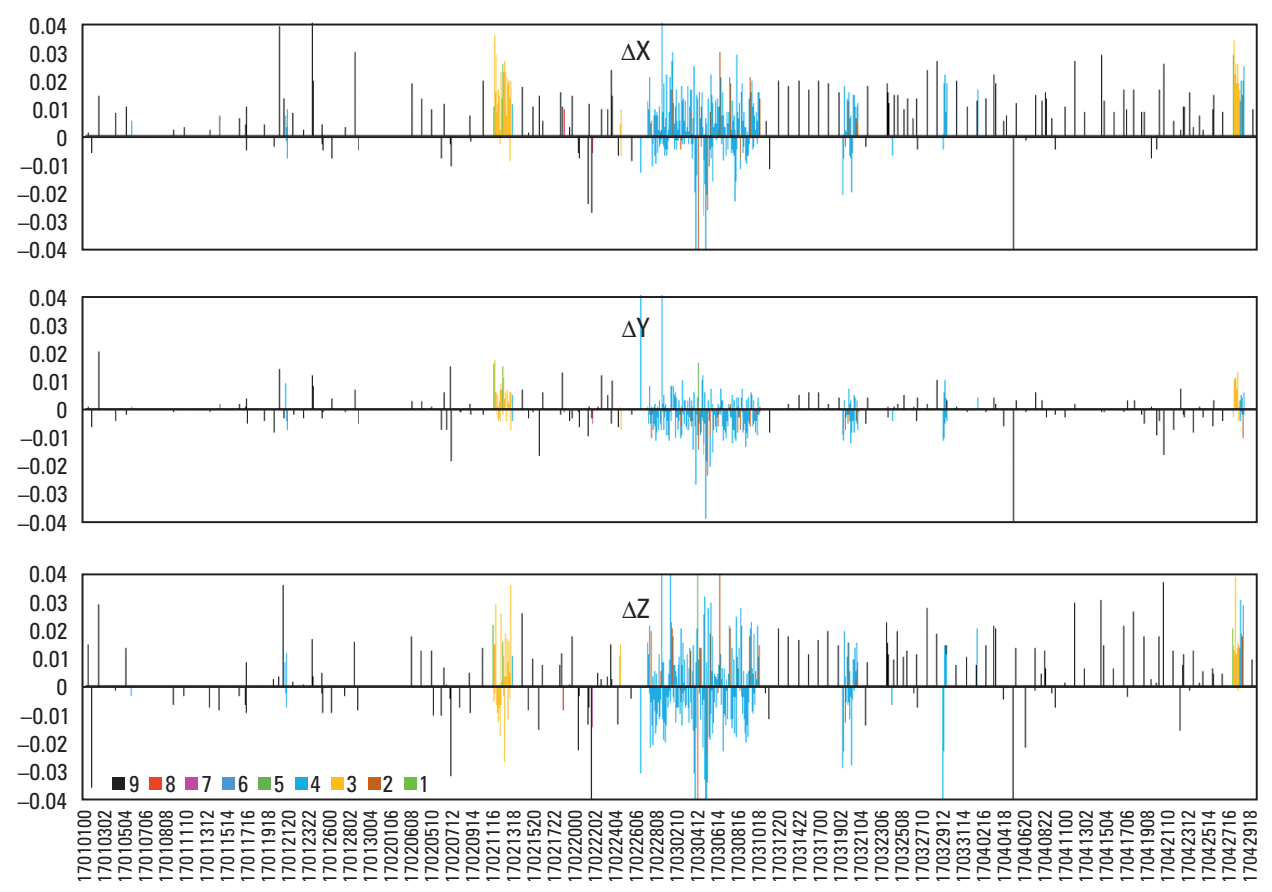

Source: Authors' own study

Fig. 3. The linear deviations of coordinates from reference coordinates for alternative solutions

Next, the lengths of vectors between the positions obtained from simulated alternative combinations and reference positions were considered. This yielded insight into the distribution of points around the reference point in 3D buffers, $0.01 \mathrm{~m}$ wide. The downside of this analysis was the fact that the information about the orientation and sense of the spatial vector indicating the location of points around the reference position was lost. Hence, the analysis only involved one dimension. The calculated lengths 

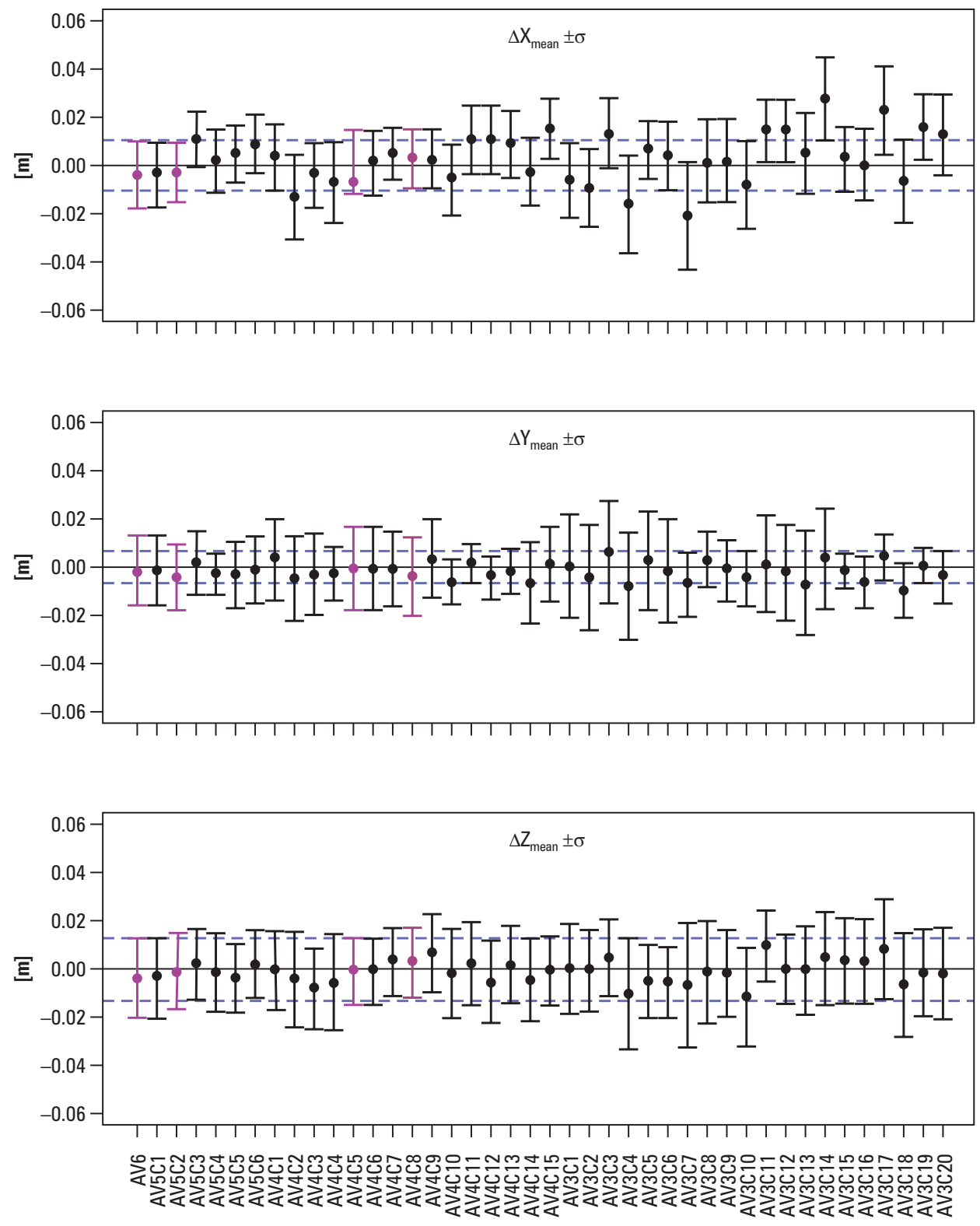

Variants and combinations

Source: Authors' own study

Fig. 4. Mean values of deviations $\Delta \mathrm{X}, \Delta \mathrm{Y}, \Delta \mathrm{Z}$ with values of standard deviations for the combinations in the set of alternative solutions with mean values (blue lines) and standard deviations (blue dashed lines) of the standard solution; simulated combinations observed in the case of real failures of reference stations in the analysed period (magenta), other simulated combinations (black) 
of vectors, both for the AV6 set of solutions and for each combination possible within the variants, were clustered into five intervals depending on the magnitude of the vector (Fig. 5). Intervals of $0.01 \mathrm{~m}$ were used. For values exceeding $0.05 \mathrm{~m}$, an overflow interval was used. For the AV6 solution, approximately $75 \%$ of vectors assume values from the range $0.00 \mathrm{~m}$ to $0.02 \mathrm{~m}$. For the AV6 solution, the sphere with $0.01 \mathrm{~m}$ radius contains about $35 \%$ of the resulting points, which is also characteristic of combinations $\mathrm{AV} 5 \mathrm{C} 1, \mathrm{AV} 5 \mathrm{C} 2, \mathrm{AV} 4 \mathrm{C} 8$, and AV3C15. What is interesting, more points are clustered closer to the reference position for AV4C5, AV4C6 and AV4C7 than for the AV6 solution. Similar values were obtained for all combinations of 5 tie vectors and for AV4C8, AV3C6 and AV3C15. In the case of the analysed solutions that used 5 tie vectors (AV5C1-AV5C6), there were on average $71 \%$ of points in the buffer of $0.00 \mathrm{~m}$ to $0.02 \mathrm{~m}$ around the reference point. For solutions with four tie vectors (AV4C1-AV4C15), the average was $64 \%$ of the points. For solutions with three tie vectors (AV3C1-AV3C21), the value was $52 \%$ of the points.

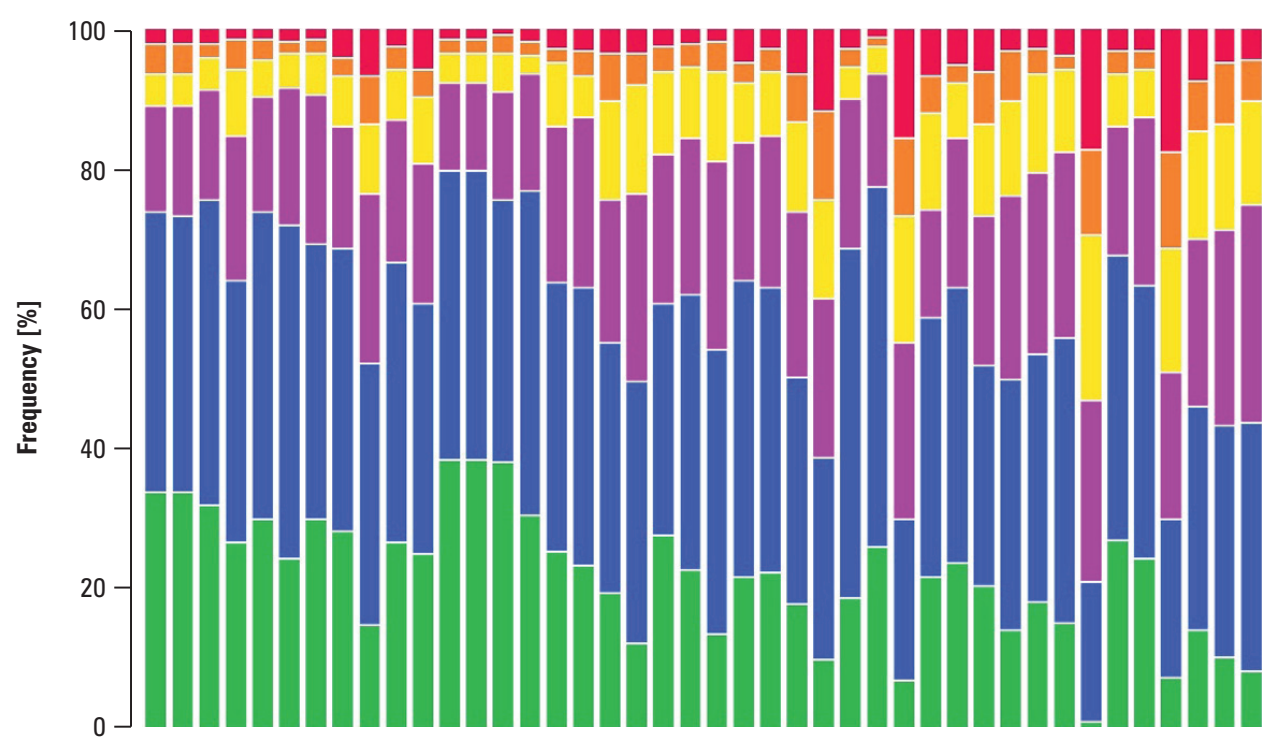

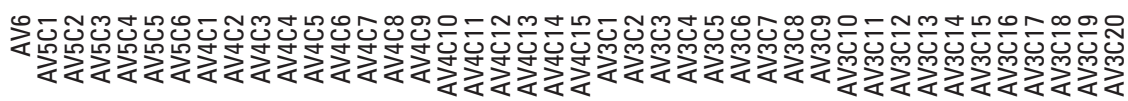

Variants and combinations

Distance: $\square=0.5 \quad(0.04 ; 0.05>\quad(0.03 ; 0.04>\square(0.02,0.03>\square(0.01 ; 0.02>\square<0 ; 0.01>$

Source: Authors' own study

Fig. 5. Lengths of 3D vectors between the determined positions and the reference position in individual length intervals for the set of AV6 solutions and each combination within the proposed variants 
MRSE, SA90, and SA99 were estimated for the sets of variants and combinations determined based on the AV6 set (Fig. 6). For the analysed AV6 solutions, MRSE was $0.03 \mathrm{~m}$, SAS 90 was $0.04 \mathrm{~m}$, and SAS99 was $0.05 \mathrm{~m}$. For the simulated solutions, MRSE ranged from 0.023 to $0.043 \mathrm{~m}$, SAS90 from 0.032 to $0.062 \mathrm{~m}$, and SAS99 from 0.043 to $0.062 \mathrm{~m}$. Better accuracy measures than that for the analysed AV6 solution were obtained for $39 \%$ of the simulated combinations, and $7 \%$ of the combinations can be considered similar thereto (Fig. 6). The highest values of the measures were identified for AV3C4, AV3C7, and AV3C14. MRSE did not exceed $0.040 \mathrm{~m}$ for $93 \%$ of the simulated combinations or SAS90 for $49 \%$ of the combinations. Hence, it can be stated with a probability of $61 \%$ that the positions determined for $93 \%$ of these combinations will not be further than $0.040 \mathrm{~m}$ from the true value. The same applies to $49 \%$ of the combinations for a probability of $90 \%$.

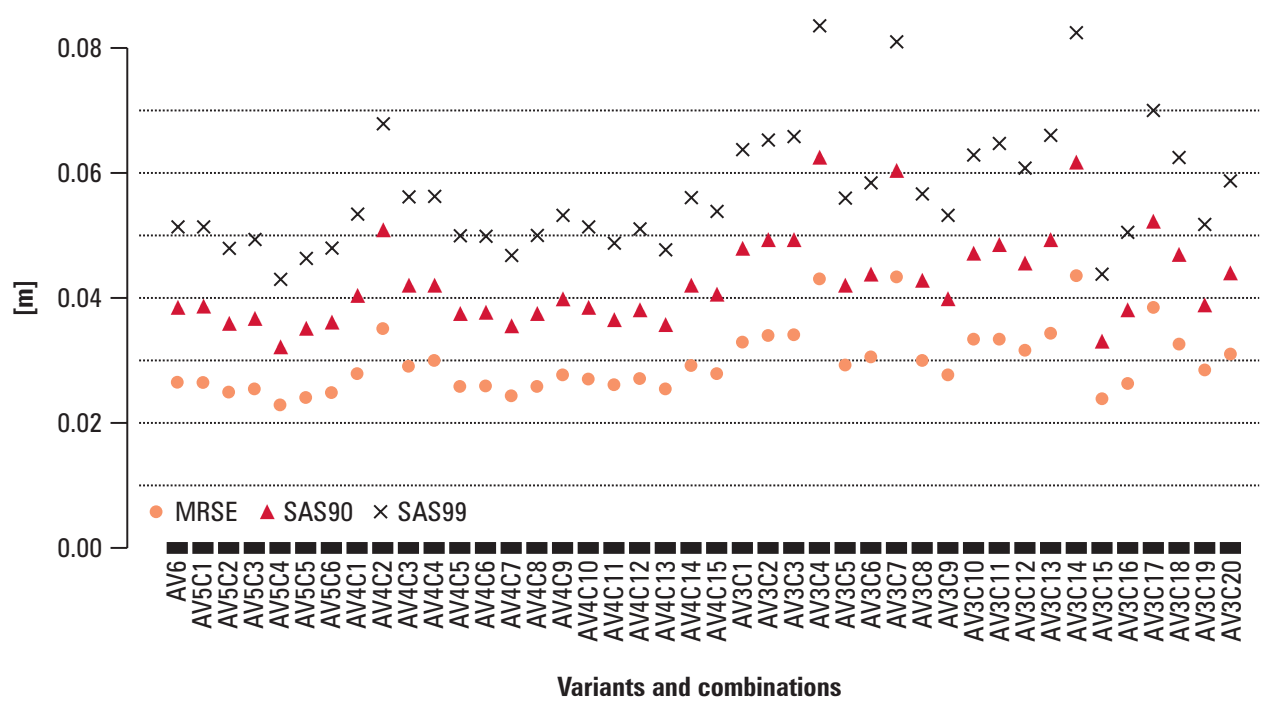

Source: Authors' own study

Fig. 6. Values of accuracy measures for the combinations of tie vectors in the set of alternative solutions

\section{Conclusions}

The paper attempts to verify the position determination using the Polish POZDGEO automatic post-processing sub-service working in ASG-EUPOS. In particular, the correctness of determining the point coordinates in the event of failure of one of the nearby reference stations involved in determining this position was verified. It was also examined whether the use of observations from a reference station over $70 \mathrm{~km}$ away would affect the results obtained for determining the position of the point. In addition, a positioning simulation was carried out based on a smaller number of tie vectors, i.e. 5 , 
4, and 3. According to EUPOS standards, the average distances between ASG-EUPOS stations should not exceed $70 \mathrm{~km}$. Therefore, spatial vectors between measuring points and tie stations with lengths not exceeding $70 \mathrm{~km}$ can be expected in most areas of Poland. Thus the vector combinations considered in the simulation may also describe other locations of measurement points in Poland.

Based on the conducted analyses, it was shown that the position of the point determined on the basis of observations from the 5 nearest stations and one more than $75 \mathrm{~km}$ away is within the range obtained if the same position was determined using observations from 6 reference stations located at a distance not greater than $70 \mathrm{~km}$. In $75 \%$ of cases, the determined position did not differ from the reference position by more than $0.02 \mathrm{~m}$. In particular, this applies to the determination of position based on 5 tie vectors. In this case, it can be argued that, with a $90 \%$ probability, the determined position will not be more than $0.04 \mathrm{~m}$ away from the reference position.

The simulation of determining the position of the point based on a smaller number of tie vectors did not significantly affect the deterioration of the position. The geometrical relationship between the tie points and the determined point was also verified in relation to whether the measured point was inside the figure, whose vertices were determined by the tie points. We have not detected any correlation between the spatial arrangement of tie points and the measured point regarding the accuracy of position determination. The quality of determining the position is more clearly influenced by the length of the vectors than by their spatial configuration. Determining the components of long vectors requires taking into account more variables [Eckl et al. 2001]. For vectors with a similar length ratio, their component errors are comparable [Borowski 2013].

The largest distances between the reference position and the determined position were noticed for the combination of 3 reference vectors. In this case, only $52 \%$ of the designated positions remained within $0.02 \mathrm{~m}$ of the reference position. As the simulation that we performed has shown, it is possible to determine a combination of 3 tie vectors that would determine the position at the same level of accuracy as though 6 tie vectors were used. Analysis of 3D position accuracy measures (MRSE, SAS90, SAS99) proved that there are combinations of tie vectors used in the case of PROS stations failure that have better accuracy than the combination of tie vectors used by POZGEO's APPS. POZGEO's APPS should be developed in the direction of a selection module of less than 6 tie stations combination in the event of failure of nearby reference stations especially if we take into account that there are combinations of less than 6 tie stations that are consistent with the standard solution, which is based on 6 tie stations.

This research project was financed by the Ministry of Science and Higher Education of the Republic of Poland (BM-2308/KG/2018 and SUB/2019-0318000000-D310).

\section{References}

Borowski Ł. 2013. Wpływ długości sesji pomiarowej na dokładność wyznaczania pozycji w pomiarach statycznych GPS. Budownictwo i Architektura, 12 (4), 251-256. 
Bosy J., Graszka W., Leończyk M. 2007. ASG-EUPOS. A Multifunctional Precise Satellite Positioning System in Poland. European Journal of Navigation, 5 (4), 2-6.

Bosy J., Oruba A., Graszka W., Leończyk M., Ryczywolski M. 2008. ASG-EUPOS densification of EUREF Permanent Network on the territory of Poland. Reports on Geodesy 2 (85), 105-112.

Eckl M.C., Snay R.A., Soler T., Cline M.W., Mader G.L. 2001. Accuracy of GPS-derived relative positions as a function of interstation distance and observing-session duration. Journal of Geodesy, 75 (12), 633-640.

EUPOS Technical Standards rev. 3, May 2013.

EUPOS Guidelines for Cross-Border Data Exchange, September 2006.

EUPOS Guideline for EUPOS Reference Frame Fixing, September 2007.

EUPOS Technical Standards rev. 2, April 2008.

EUPOS Guidelines for Single Site Design, June 2008.

Figurski M., Bogusz J., Bosy J., Kontny B., Krankowski A., Wielgosz P. 2011. „ASG+”: project for improving Polish multifunctional precise satellite positioning system. Reports on Geodesy, 2 (91), 51-57.

Kadaj R., Świętoń T. 2007a. Chapter 5: Moduł obliczeniowy. In system documentation: Automatic Postprocessing Software for Trimble Application, 2nd ed. Geotronics Sp. z o.o. and Trimble - Polska Sp. z o.o., Warsaw, Poland.

Kadaj R., Świętoń T. 2007b. Chapter 6: Zastosowane algorytmy i techniki obliczeniowe. In system documentation: Automatic Postprocessing Software for Trimble Application, 2nd ed. Geotronics Sp. z o.o. and Trimble - Polska Sp. z o.o., Warsaw, Poland.

Kadaj R. 2008. New algorithms of GPS post-processing for multiple baseline models and analogies to classic geodetic networks. Geodesy and Cartography, 57 (2), 61-79.

Kadaj R., Świętoń T. 2009. Algorytm i oprogramowanie modułu automatycznego postprocessingu w polskim systemie satelitarnych stacji referencyjnych ASG-EUPOS. Zeszyty Naukowe Budownictwo i Inżynieria Środowiska, 262, 51, 37-57.

Kadaj R. 2010. Zastosowanie różnicowego układu obserwacyjnego typu Schreibera do opracowania sesji pomiarów statycznych GPS. Biuletyn WAT, LIX, 2 (658), 85-106.

Kadaj R., Świętoń T. 2010. Moduł postprocessingu GPS w systemie GEONET. Biuletyn WAT, LIX, 2 (658), 153-162.

Kadaj R. 2012. Pól-analityczne rozwiązanie bazowe typu „float” postprocessingu GPS. Zeszyty Naukowe Budownictwo i Inżynieria Środowiska, 283, 59, 169-180.

Kadaj R., Świętoń T. 2016. Theoretical and applied research in the field of higher geodesy conducted in Rzeszow. Reports on Geodesy and Geoinformatics, 100 (1), 79-100.

Krzeszowski K., Bosy J. 2011. ASG-EUPOS w terenach przygranicznych. Acta Scientiarum Polonorum, ser. Geodesia et Descriptio Terrarum, 10 (1), 33-41.

Kudas D. 2015. Analiza powtarzalności wyznaczenia współrzędnych punktu osnowy pomiarowej w czasie 24 godzin z krótkich sesji obserwacyjnych. Episteme. Czasopismo Naukowo-Kulturalne, 2, 26, 83-92.

Paziewski J., Krukowska M., Wielgosz P. 2014. Preliminary results on performance of new ultra-fast static positioning module POZGEO-2 in areas outside the ASG-EUPOS network. Geodesy and Cartography, 63 (1), 101-109.

Regulation 2012. Rozporządzenie Ministra Administracji i Cyfryzacji z dnia 14 lutego 2012 r. w sprawie osnów geodezyjnych, grawimetrycznych i magnetycznych (Dz. U. z 2012 r., poz. 352).

Specht C., Skóra M. 2009. Analiza porównawcza wybranych aktywnych sieci geodezyjnych. Comparative analysis of selected active geodetic networks. Zeszyty Naukowe Akademii Marynarki Wojennej, XLX, 3 (178), 39-54.

www.asgeupos.pl (accessed: 15 March 2019). 
Mgr inż. Dawid Kudas

Uniwersytet Rolniczy w Krakowie

Katedra Geodezji

30-198 Kraków, ul. Balicka 253a

e-mail: dawid.kudas@gmail.com

ORCID: https://orcid.org/0000-0003-1109-114X

Dr inż. Agnieszka Wnęk

Uniwersytet Rolniczy w Krakowie

Katedra Geodezji

30-198 Kraków, ul. Balicka 253a

e-mail: ag.wnek@urk.edu.pl

ORCID: https://orcid.org/0000-0001-8669-2519 